Polish Journal of Microbiology

2012, Vol. 61, No 4, 281-289

ORGINAL PAPER

\title{
Production and Characteristics of a Heavy Metals Removing Bioflocculant Produced by Pseudomonas aeruginosa
}

\author{
EMAN ZAKARIA GOMAA* \\ Department of Biological and Geological Sciences, Faculty of Education, \\ Ain Shams University, Roxy, Cairo, Egypt
}

Received 10 February 2012, accepted 20 September 2012

\section{Abstract}

The flocculating activity of a bioflocculant produced by Pseudomonas aeruginosa ATCC-10145 using kaolin clay was assayed. The influence of carbon, nitrogen sources, $\mathrm{pH}$ and culture temperature on bioflocculant production was investigated. The effects of cationic compounds, bioflocculant dosage, $\mathrm{pH}$ and temperature on flocculating activity were also determined. Of the cations tested, $\mathrm{Ca}^{2+}, \mathrm{K}^{+}, \mathrm{Na}^{+}, \mathrm{Zn}^{2+}, \mathrm{Mg}^{2+}$ and $\mathrm{Cu}^{2+}$ improved flocculating activity whereas $\mathrm{Fe}^{3+}$ and $\mathrm{Al}^{3+}$ caused its inhibition. The highest flocculating activity was observed at $\mathrm{pH}$ 7.0.The bioflocculant had a good flocculating activity of $80.50 \%$ for kaolin suspension with a dosage of only $1 \%$. The bioflocculant was heat-stable and its activity was only decreased to $60.16 \%$ after heating at $100^{\circ} \mathrm{C}$ for $60 \mathrm{~min}$. Chemical analyses of the purified bioflocculant indicated that it was a sugar-protein derivative, composed of protein $(27 \%, w / w)$ and carbohydrate $(89 \%, w / w)$ including neutral sugar, uronic acid and amino sugar as the principal constituents in the relative weight proportions of $30.6 \%, 2.35 \%$ and $0.78 \%$, respectively. The elemental analysis of the bioflocculant revealed the mass proportion of $\mathrm{C}, \mathrm{H}$ and $\mathrm{N}$ was 19.06, 3.88 and $4.32(\%)$, correspondingly. Fourier transform infrared analysis showed that the exopolymers consisted of carboxyl, hydroxyl, amino and sugar derivative groups. The heavy metal adsorption by the bioflocculant of Pseudomonas aeruginosa was found to be influenced by the initial metal concentration, bioflocculant concentration and $\mathrm{pH}$ of the biosorption solution. This study demonstrates that microbial bioflocculant has potential to be used as an alternative bioremedial tool for industrial effluents and wastewater treatments which are co-contaminated with heavy metals.

Ke y word s: Pseudomonas aeruginosa, bioflocculant, biosorption, removal heavy metals

\section{Introduction}

Flocculants are special natural organic macromolecule substances that can flocculate suspended solids, cells, colloidal solids, etc (Zhang, 2005). They are widely used in material separation processes, such as drinking water purification, waste water treatment, dehydration of activated sludge, dredging, down stream processing, food and fermentation process (Salehizadeh and Shojaosadati, 2001).

Flocculating agents are generally classified into three groups: (1) inorganic flocculants, such as aluminum sulfate and polyaluminum chloride (2) organic synthetic flocculants, such as polyacrylamide derivatives and polyethylene imine (3) naturally occurring flocculants, such as chitosan, sodium alginate and bioflocculant (Zhang et al., 2007).

Despite the effective flocculation performance and low cost of the synthetic chemical flocculants, their use has resulted in some health and environmental prob- lems. For example, aluminum has been found to induce Alzheimer's disease (Arezoo, 2002). Furthermore, the acrylamide monomer is not only toxic and carcinogenic, but also non-biodegradable in nature (Ruden, 2004). On the contrary, bioflocculant has attracted considerable attention as a promising substitute for chemical flocculants because of their biodegradability and safety for ecosystems (He et al., 2004). Further, bioflocculants can be produced economically on a large scale and easily be recovered from fermentation broth. Therefore, they now have wide applications in many industrial sectors associated with textiles, detergents, adhesives, microbial enhanced oil recovery, and wastewater treatment (Kumar et al., 2004).

Heavy metals are introduced into the aquatic systems significantly as a result of various industrial operations that include agriculture, battery production, fossil fuel burning, mining and metallurgical processes (Boening, 2000). Heavy metals are a critical concern to human health and environmental issues due to their

* Corresponding author: Eman Zakaria Gomaa, Department of Biological and Geological Sciences, Faculty of Education, Ain Shams University, Roxy, 11435 Cairo, Egypt; e-mail: emann7778@yahoo.com 
high occurrence as a contaminant, present in soluble form that are extremely toxic to biological systems, and the classification of several heavy metals as carcinogenic and mutagenic (Diels et al., 2002). Moreover, the metals cannot be degraded to harmless products and hence persist in the environment indefinitely. As a result, several methods have been devised for the treatment and removal of heavy metals in contaminated sites. Conventional techniques for the removal of heavy metals from wastewater, such as chemical precipitation, ion exchange, activated carbon adsorption and separation processes have limitations and become inefficient and expensive especially when the heavy metal concentration is less than $100 \mathrm{ppm}$ (Yan and Viraraghavan, 2001). Finding an effective method of removal of toxic heavy metals from industrial waste water is essential from the stand point of environmental pollution control and it has directed attention to biosorption, based on the metal binding capacities of various biological materials (Al-Garni et al., 2009).

To utilize bioflocculants widely in industrial fields, it is desirable to find various microorganisms with high bioflocculant-producing ability and improve the flocculating efficiency of the produced bioflocculant. Consequently, this study aims to investigate the ability of Pseudomonas aeruginosa to produce bioflocculant. The study also includes optimization, purification and characterization of the produced bioflocculant. Moreover, the flocculating activities of the bioflocculant produced in the removal of various heavy metals which are normally present in wastewater treatment are reported in this paper.

\section{Experimental}

\section{Materials and Methods}

Bacterial strain. A bioflocculant-producing strain, Pseudomonas aeruginosa ATCC-10145 was kindly obtained from Fermentation Biotechnology and Applied Microbiology (FERM-BAM) Center, Al-Azhar University, Cairo, Egypt. The bacterium was preserved on agar slants and glycerol (20\%) stocks maintained at $-80^{\circ} \mathrm{C}$.

Media and cultivation conditions. The strain was pre-cultured in $50 \mathrm{ml}$ medium in $250 \mathrm{ml}$ flasks on a rotary shaker $(200 \mathrm{rpm})$ at $30^{\circ} \mathrm{C}$ for inoculation preparation. After $24 \mathrm{~h}$ of cultivation, the culture broth was used as a seed culture and $1 \%$ of it was inoculated into $100 \mathrm{ml}$ of fermentation medium in $500 \mathrm{ml}$ flask for $48 \mathrm{~h}$. The seed medium contained (per liter) glucose, 10 g; yeast extract, $0.5 \mathrm{~g}$; urea, $0.5 \mathrm{~g}$; $\mathrm{KH}_{2} \mathrm{PO}_{4}, 0.1 \mathrm{~g}$; $\mathrm{NaCl}, 0.1 \mathrm{~g}$; and $\mathrm{MgSO}_{4} .7 \mathrm{H}_{2} \mathrm{O}, 0.2 \mathrm{~g}, \mathrm{pH}$. The fermentation medium contained (per liter) sucrose, 10 g; yeast extract, $1 \mathrm{~g}$; urea, $1 \mathrm{~g} ; \mathrm{KH}_{2} \mathrm{PO}_{4}, 0.1 \mathrm{~g} ; \mathrm{K}_{2} \mathrm{HPO}_{4}, 0.1 \mathrm{~g}$; $\mathrm{NaCl}, 0.1 \mathrm{~g}$; and $\mathrm{MgSO}_{4} \cdot 7 \mathrm{H}_{2} \mathrm{O}, 0.2 \mathrm{~g}$, pH7 (Xiong et al.,
2010). After incubation, the culture broth was centrifuged at $10000 \mathrm{xg}$ for $30 \mathrm{~min}$. The cell-free culture supernatant was the liquid bioflocculant, which was used for the analysis of flocculating activity.

Determination of flocculating activity. The flocculating activity was measured using a kaolin clay suspension. First, $0.5 \mathrm{~g}$ kaolin clay was suspended in $100 \mathrm{ml}$ distilled water, and $0.5 \mathrm{ml}$ of the liquid bioflocculant was mixed thoroughly with $45 \mathrm{ml}$ of the kaolin suspension. Then, $4.5 \mathrm{ml}$ of $1 \% \mathrm{CaCl}_{2}$ solution was added to the mixture. The mixture was stirred with a vortex mixer and left standing for $5 \mathrm{~min}$ at room temperature. The optical density (O.D) of the supernatant and the blank control where distilled water was used instead of the supernatant was measured at $550 \mathrm{~nm}$. The flocculating activity was defined and calculated as follows (Flocculating activity $=(\mathrm{A}-\mathrm{B}) / \mathrm{A} \times 100$, where $\mathrm{A}$ and $\mathrm{B}$ are the optical densities at $550 \mathrm{~nm}$ of the control and the sample, respectively (Zhang et al., 2007).

Optimization of bioflocculant production. In order to optimize the nutritional and environmental factors affecting bioflocculant production by Pseudomonas aeruginosa, the following variables were assayed: incubation period (1-5 days), carbon source (glucose, fructose, sucrose, lactose, galactose, mannose, maltose, starch, sodium acetate, citric acid, glycerol and ethanol), nitrogen source (yeast extract, beef extract, peptone, urea, glutamic acid, ammonium sulphate, ammonium nitrate, ammonium chloride and sodium nitrate), initial $\mathrm{pH}$ (pH5-12) and incubation temperature $\left(20,25,30,35\right.$ and $\left.40^{\circ} \mathrm{C}\right)$. All experiments were performed in triplicate for calculation of the mean. Medium samples were withdrawn and monitored for final $\mathrm{pH}$, cell growth (cell dry weight) and flocculating activity as described above.

Characteristics of the bioflocculant. The effect of different cations on flocculating activity was studied by addition of $\mathrm{CaCl}_{2}, \mathrm{KCl}, \mathrm{MgCl}_{2}, \mathrm{NaCl}, \mathrm{ZnSO}_{4}$, $\mathrm{CuSO}_{4}, \mathrm{FeCl}_{3}$ and $\mathrm{AlCl}_{3}$ at a concentration of $(1 \mathrm{mM})$. The effect of different bioflocculant dosages was investigated by adding different amounts of liquid bioflocculant $(1,2,3,4$ and 5\%) to a constant concentration of kaolin suspension $(0.5 \%)$ at $\mathrm{pH} 7$ containing $\mathrm{CaCl}_{2}$ (1\%). A control was prepared with distilled water in place of bioflocculant. To estimate the influence of $\mathrm{pH}$ value on the flocculating activity, the reaction mixture was adjusted to $\mathrm{pH}$ value ranged from (3-11) using $\mathrm{HCl}$ or $\mathrm{NaOH}$. The effect of temperature was studied at a temperature range of $40-90^{\circ} \mathrm{C}$ for $30^{\circ} \mathrm{C}$. Boiling of the reaction mixture at $100^{\circ} \mathrm{C}$ for $1-60 \mathrm{~min}$ was also studied. In each case, the remaining flocculating activity of each sample was measured and calculated using the procedure described above.

Bioflocculant purification. Two volumes of cold ethanol were added to supernatant of the culture broth 
to precipitate the bioflocculant and the mixture was left overnight at $4^{\circ} \mathrm{C}$. The precipitate collected by centrifugation at $10000 \mathrm{xg}$ for $30 \mathrm{~min}$ was dialyzed against de-ionized water overnight and then lyophilized and weighed.

Chemical analysis. Total carbohydrate content of the bioflocculant was measured by phenol-sulfuric acid method (Chaplin and Kennedy, 1994) using glucose as the standard solution. Protein was determined by the method of Lowry et al. (1951) with bovine serum albumin as a standard. Amino acid was estimated by ninhydrin method (Zhang, 2003). After hydrolysis of the bioflocculant with $2 \mathrm{M}$ trifluroacetic acid at $120^{\circ} \mathrm{C}$ for $2 \mathrm{~h}$, neutral sugars, uronic acids and amino sugars were determined with anthrone method, carbazole sulfate acid method and the Elson-Morgan method, respectively using the procedure of Chaplin and Kennedy (1994). The percentage of carbon, hydrogen, nitrogen and sulfur of the purified bioflocculant were determined using Atomic Absorption Spectrophotometer (Perkin Elemer USA, Model 2400).

Fourier transform infrared spectroscopy. The purified bioflocculant ( $2 \mathrm{mg}$ ) was ground with $100 \mathrm{mg}$ $\mathrm{KBr}$ and compressed at 7'500 $\mathrm{kg}$ for $3 \mathrm{~min}$ to obtain translucent pellets. $\mathrm{KBr}$ pellet was used as the background reference. Infrared absorption spectra were recorded with a model (Jasco FTIR-6100, Japan). The spectral resolution and wave number accuracy were 4 and $0.01 \mathrm{~cm}^{-1}$, respectively.

Heavy metal adsorption. The potential of the produced bioflocculant for removing heavy metals was assessed as described by Lin and Harichund (2011). The metal salts used were copper sulphate, lead acetate, sodium arsenate, zinc sulphate, cadmium chloride and mercury iodide (Sigma Co). $5 \mathrm{ml}$ bioflocculant solution was put into dialysis tubing in flasks containing $200 \mathrm{ml}$ of each appropriate metal-salt solution and shaken at $100 \mathrm{xg}$ for $24 \mathrm{~h}$ at $30^{\circ} \mathrm{C}$. The quantity of metal removed from the solution, i.e. bound to the polymer, was calculated by measuring the ions in solution at $0 \mathrm{~h}$ and those remaining after $24 \mathrm{~h}$ by Atomic Absorbance Spectrometer (Perkin Elemer USA, Model 2400) and the percentage of each metal removal was calculated (Gourdon et al., 1990). Controls were made by placing $5 \mathrm{ml}$ distilled water in dialysis tubing with the various metal-salt solutions. The effect of heavy metal concentrations $(20,40,60,80$, and $100 \mathrm{ppm})$ bioflocculant concentrations $(100,1000,5000$ and $10000 \mathrm{ppm})$ and $\mathrm{pH}$ value (3, 5, 7 and 9) on the metal adsorption by the biopolymer was investigated.The adsorption test procedure as well as the calculation of percentage of each metal removing were the same as described above.

Statistical analysis. All experiments were performed in triplicate and the results were expressed as means + SD.

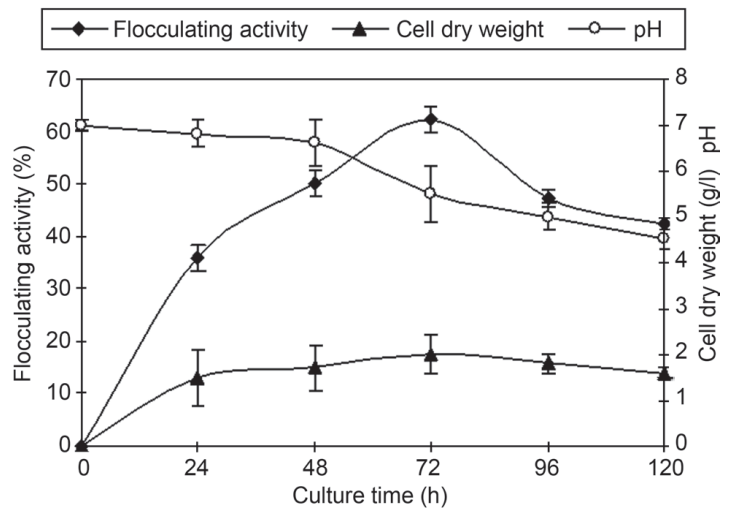

Fig. 1. Time courses of the growth, $\mathrm{pH}$, and flocculating activity of culture broth of Pseudomonas aeruginosa cultivated on a rotary shaker at $200 \mathrm{rpm}$ and $30^{\circ} \mathrm{C}$ for $120 \mathrm{~h}$.

\section{Results and Discussion}

Time course assay of bioflocculant production. The growth curve of Pseudomonas aeruginosa strain, the flocculating activity and $\mathrm{pH}$ variation of the culture broth are shown in Fig. 1. During growth, Pseudomonas aeruginosa showed acidification activity and the flocculating activity increased as the cultivation period increased, attaining peak flocculating activity of about $62.25 \%$ after $72 \mathrm{~h}$ of cultivation, beyond which flocculating activity began to decline. The flocculating activity increased in parallel with cell growth, indicating extracellular accumulation of bioflocculants in the medium during the active growth phase. This suggests that the bioflocculant was produced by biosynthesis during growth of the bacterium and not by cell autolysis (Lu et al., 2005). The observed decrease in flocculating activity might be due to partial enzymatic degradation of the polymer flocculant in the late phases of cell growth (Choi et al., 1998).

Factors affecting bioflocculant production. It is well known that optimization of the cultivation process is a rather powerful approach to improve the production of bioproducts. The bioflocculant production is affected by many factors, such as the constituents of the culture medium and environmental conditions ( $\mathrm{He}$ et al., 2004).The effects of the key factors, like carbon, nitrogen sources, initial $\mathrm{pH}$ and culture temperature on bioflocculant production by Pseudomonas aeruginosa were investigated with an aim to identify the costoptimal culture conditions.

It has been well documented that changing the carbon and nitrogen sources highly influences bacterial growth and bioflocculant production (Sheng et al., 2006). From Table I, one noteworthy result was that the bacteria grew and produced bioflocculant with all the carbon sources assayed. Ethanol seems to be the 
Table I

Effect of carbon source in the production medium on flocculating activity of the bioflocculant produced by Pseudomonas aeruginosa

\begin{tabular}{|l|c|c|}
\hline \multicolumn{1}{|c|}{ Carbon source } & $\begin{array}{c}\text { Flocculating activity } \\
(\%)\end{array}$ & $\begin{array}{c}\text { Bacterial growth } \\
(\mathrm{g} / \mathrm{l})\end{array}$ \\
\hline Glucose & $39.50 \pm 2.11$ & $1.0 \pm 0.03$ \\
\hline Fructose & $50.38 \pm 1.67$ & $1.6 \pm 0.84$ \\
\hline Sucrose & $50.25 \pm 2.41$ & $2.0 \pm 0.95$ \\
\hline Lactose & $48.38 \pm 1.25$ & $1.8 \pm 0.86$ \\
\hline Galactose & $33.80 \pm 1.58$ & $0.9 \pm 0.04$ \\
\hline Mannose & $48.28 \pm 1.41$ & $1.4 \pm 0.94$ \\
\hline Maltose & $53.42 \pm 2.99$ & $1.6 \pm 0.01$ \\
\hline Starch & $39.52 \pm 2.32$ & $2.0 \pm 0.00$ \\
\hline Sodium acetate & $46.95 \pm 1.63$ & $1.4 \pm 0.90$ \\
\hline Citric acid & $46.00 \pm 1.48$ & $1.5 \pm 0.02$ \\
\hline Glycerol & $61.61 \pm 2.02$ & $2.5 \pm 0.00$ \\
\hline Ethanol & $70.14 \pm 4.20$ & $3.0 \pm 0.06$ \\
\hline
\end{tabular}

Table II

Effect of nitrogen source in the production medium on flocculating activity of the bioflocculant produced by Pseudomonas aeruginosa

\begin{tabular}{|l|c|c|}
\hline \multicolumn{1}{|c|}{ Nitrogen source } & $\begin{array}{c}\text { Flocculating } \\
\text { activity }(\%)\end{array}$ & $\begin{array}{c}\text { Bacterial } \\
\text { growth }(\mathrm{g} / \mathrm{l})\end{array}$ \\
\hline Yeast extract & $52.60 \pm 3.04$ & $1.4 \pm 0.74$ \\
\hline Yeast extract + beef extract & $65.63 \pm 3.74$ & $2.4 \pm 0.00$ \\
\hline Yeast extract + peptone & $56.31 \pm 1.12$ & $1.0 \pm 0.22$ \\
\hline Yeast extract + urea & $70.23 \pm 2.9$ & $3.0 \pm 0.46$ \\
\hline Yeast extract + glutamic acid & $55.88 \pm 1.74$ & $1.4 \pm 0.03$ \\
\hline Yeast extract $+\mathrm{NH}_{4} \mathrm{SO}_{4}$ & $65.04 \pm 4.88$ & $2.7 \pm 0.42$ \\
\hline Yeast extract $+\left(\mathrm{NH}_{4}\right) \mathrm{NO}_{3}$ & $66.78 \pm 1.34$ & $2.8 \pm 0.86$ \\
\hline Yeast extract $+\mathrm{NH}_{4} \mathrm{Cl}$ & $68.81 \pm 1.18$ & $2.4 \pm 0.00$ \\
\hline Yeast extract $+\mathrm{NaNO}_{3}$ & $78.24 \pm 1.47$ & $3.6 \pm 0.04$ \\
\hline Urea & $68.70 \pm 2.42$ & $2.0 \pm 0.01$ \\
\hline Urea + beef extract & $70.08 \pm 1.52$ & $2.6 \pm 0.09$ \\
\hline Urea + peptone & $61.71 \pm 3.24$ & $2.4 \pm 0.03$ \\
\hline Urea + glutamic acid & $49.97 \pm 3.77$ & $2.0 \pm 0.72$ \\
\hline Urea $+\mathrm{NH}_{4} \mathrm{SO}_{4}$ & $69.02 \pm 1.12$ & $2.4 \pm 0.14$ \\
\hline Urea $+\left(\mathrm{NH}_{4}\right) \mathrm{NO}_{3}$ & $69.44 \pm 2.20$ & $2.6 \pm 0.56$ \\
\hline Urea $+\mathrm{NH}_{4} \mathrm{Cl}$ & $70.65 \pm 0.88$ & $2.4 \pm 0.90$ \\
\hline Urea $+\mathrm{NaNO}_{3}$ & $47.60 \pm 1.34$ & $2.6 \pm 0.00$ \\
\hline
\end{tabular}

preferred carbon source for bioflocculant production by Pseudomonas aeruginosa. The flocculating rate of the culture reached $70.14 \%$, therefore, it was chosen to be the carbon source for bioflocculant production in the subsequent studies. Similarly, ethanol was the favored carbon sources for bioflocculant production by Rhodococcus erythropolis (Kurane et al., 1991) and Klebsiella pneuminiae (Nakata and Kurane, 1999). Ethanol was also a good carbon source for bioflocculant production in the industrial scale. Wastes from canning factories' and stillage from distilleries are alternatives for expensive carbon sources (Tong et al., 1999).

With respect to the effect of nitrogen source on bioflocculant production, it can be observed from Table II that multiple nitrogen sources were better than a single nitrogen source. The medium containing yeast extract and sodium nitrate was the most favorable for production of bioflocculant as they caused the highest bioflocculant activity (78.24\%).

It well known that the initial $\mathrm{pH}$ of the fermentation medium affected bioflocculant synthesis as it determines the electric charge of the cells and the oxidation-reduction potential which can affect nutrient absorption and enzymatic reaction (Xia et al., 2008). The flocculating activity of the culture broth reached a maximum at $\mathrm{pH} 7.0$ (78.24\%) and then gradually decreased with increase of initial pH (data not shown). However, production of bioflocculant in acidic conditions was distinctly much lower than in either neutral or alkaline ones. Comparison between final $\mathrm{pH}$ and initial $\mathrm{pH}$ values clearly presented that the cultural medium had the buffer capability especially in alkaline conditions. This buffer ability may come from the organic acid contained in bioflocculant, by-production like acetic acid, or the unspent $\mathrm{K}_{2} \mathrm{HPO}_{4}$ and $\mathrm{KH}_{2} \mathrm{PO}_{4}$.

Concerning incubation temperature, various culture temperatures were tested in order to investigate their effect on bioflocculant production. The maximum flocculating activity was $80.50 \%$, which was recorded at $35^{\circ} \mathrm{C}$.The activity dropped drastically when the cultivation temperature fell below $30^{\circ} \mathrm{C}$ or increased above $40^{\circ} \mathrm{C}$ (data not shown). The metabolism of microorganisms has a direct relationship with cultivating temperature; maximum enzymatic activation can only be obtained at optimal temperature (Zhang et al., 2007). A lower culture temperature might make the strain hibernate partially, and its enzyme system for bioflocculant production could not be activated completely. On the other hand, a higher culture temperature may have an adverse effect on the nucleic acid and enzyme system of the strain, further on the bioflocculant production.

Bioflocculant characterization. Bioflocculant characterization was determined using kaolin clay suspension as a flocculation test material because kaolin is a well-known and wide spread thickening agent. Also the surface characteristics of kaolin are well-understood to allow analysis, and in consequence kaolin has received great interest in recent years (Nasser and James, 2007).

The results of the present study indicate that environmental parameters like cationic compounds, bioflocculant dosage, $\mathrm{pH}$ and temperature play an important role in the flocculating activity of the produced bioflocculant. 
Table III

Factors affecting flocculating activity of the bioflocculant produced by Pseudomonas aeruginosa

\begin{tabular}{|c|c|c|c|c|c|}
\hline Cations (1 mM) & Flocculating activity (\%) & Temperature $\left({ }^{\circ} \mathrm{C}\right)$ & Flocculating activity (\%) & $\mathrm{pH}$ & Flocculating activity (\%) \\
\hline Control & $80.50 \pm 1.89$ & 40 & $80.10 \pm 2.42$ & 3 & $12.45 \pm 0.00$ \\
\hline $\mathrm{Ca}^{+}$ & $95.42 \pm 2.43$ & 50 & $78.89 \pm 4.66$ & 4 & $21.12 \pm 5.22$ \\
\hline $\mathrm{K}^{+}$ & $90.70 \pm 5.20$ & 60 & $78.50 \pm 1.45$ & 5 & $64.50 \pm 1.14$ \\
\hline $\mathrm{Mg}^{2+}$ & $92.39 \pm 1.72$ & 70 & $77.90 \pm 2.13$ & 6 & $72.95 \pm 1.17$ \\
\hline $\mathrm{Na}^{+}$ & $96.16 \pm 4.20$ & 80 & $77.45 \pm 0.00$ & 7 & $80.50 \pm 3.70$ \\
\hline $\mathrm{Zn}^{2+}$ & $84.53 \pm 2.04$ & 90 & $76.53 \pm 1.22$ & 8 & $63.80 \pm 0.80$ \\
\hline $\mathrm{Cu}^{2+}$ & $80.80 \pm 1.22$ & $100(1 \mathrm{~min})$ & $74.00 \pm 3.84$ & 9 & $60.42 \pm 1.12$ \\
\hline $\mathrm{Fe}^{3+}$ & $62.49 \pm 1.04$ & $100(5 \mathrm{~min})$ & $72.35 \pm 1.88$ & 10 & $55.45 \pm 1.18$ \\
\hline $\mathrm{Al}^{3+}$ & $65.88 \pm 1.20$ & $100(1 \mathrm{~min})$ & $70.76 \pm 1.43$ & 11 & $50.45 \pm 1.20$ \\
\hline $\begin{array}{l}\text { Flocculant } \\
\text { concentration (\%) }\end{array}$ & $\begin{array}{l}\text { flocculating } \\
\text { activity (\%) }\end{array}$ & $100(10 \mathrm{~min})$ & $65.35 \pm 2.22$ & & \\
\hline 1 & $80.50 \pm 2.13$ & $100(20 \mathrm{~min})$ & $64.96 \pm 1.34$ & & \\
\hline 2 & $75.16 \pm 1.28$ & $100(30 \mathrm{~min})$ & $64.12 \pm 2.44$ & & \\
\hline 3 & $70.39 \pm 1.00$ & $100(40 \mathrm{~min})$ & $62.15 \pm 1.00$ & & \\
\hline 4 & $60.11 \pm 2.25$ & $100(50 \mathrm{~min})$ & $62.00 \pm 1.02$ & & \\
\hline 5 & $55.16 \pm 2.63$ & $100(60 \mathrm{~min})$ & $60.16 \pm 1.74$ & & \\
\hline
\end{tabular}

The influence of cations on flocculating activities was studied and compared. As presented in Table III, the flocculating activity of bioflocculant from Pseudomonas aeruginosa was a cation-dependent whose flocculating capability was strongly increased by $\mathrm{Ca}^{2+}$, $\mathrm{K}^{+}, \mathrm{Na}^{+}, \mathrm{Zn}^{2+}, \mathrm{Mg}^{2+}$ and $\mathrm{Cu}^{2+}$, and dropped by the addition of $\mathrm{Fe}^{3+}$ and $\mathrm{Al}^{3+}$ compared with that of the control. Cations stimulate flocculating by accelerating bridge formation between suspended particles and bioflocculant. Moreover, the bivalent cations increase the initial adsorption of biopolymers on suspended particles by neutralizing negatively charged functional groups of both the bioflocculant molecules and the suspended particles and consequently weaken the static repulsive force thus enhancing the flocculation effect (Li et al., 2008). However, the presence of metal is not absolutely essential for bacterial biofloculating activities. For example, bioflocculants produced by Citrobacter sp. TKF04 (Fujita et al., 2000) and Bacillus sp. F19 w (Zheng et al., 2008) were capable of flocculating kaolin clay without metals.

Concentration of the bioflocculant played an important role in bioflocculating activity, the maximum flocculation of $80.50 \%$ was recorded at $1 \%$ bioflocculant (Table III). Flocculation mainly ceased once the bioflocculant concentration exceeded as the adsorption of excess bioflocculant re-stabilized the kaolin particles; thus the attractive forces of other particles were reduced and flocculating activity decreased (Suh et al., 1997).

The effect of $\mathrm{pH}$ on flocculating activity was examined at $\mathrm{pH}$ values ranging from 3 to11 (Table III). The activity was found to be the highest $(80.50 \%)$ at $\mathrm{pH} 7$. Gao et al. (2006) and He et al., 2010 reported similar optimal pH value (7.0) for the activity of the bioflocculants produced by Vagococcus sp. and a mutant Halomonas sp., respectively. At low and high $\mathrm{pH}$ values, the absorption of $\mathrm{H}^{+}$ions tends to weaken the bioflocculant-kaolin complex formation process.

The flocculants with protein or peptide backbone in the structure are generally thermally labile, but those made of sugars are heat-stable. If the major component of a bioflocculant is a glycoprotein, its stability will depend on the relative contents of protein and polysaccharide (Takagi and Kadowaki, 1985). In this study, the major component of bioflocculant is a polysaccharide, and it shows heat stability (Table III). The bioflocculant maintained its stability under heating and flocculating activity was decreased only to $60.16 \%$ after heating at $100^{\circ} \mathrm{C}$ for $60 \mathrm{~min}$, suggesting that the bioflocculant produced by Pseudomonas aeruginosa is thermo-stable.

The above mentioned characteristics demonstrate that the bioflocculant has strong flocculating activity and high stable quality, which affords high possibility of its practical use in industries and environmental applications. About $2.4 \mathrm{~g}$ bioflocculant was recovered from 1.01 of fermentation broth, which was markedly higher than reported in the literature (Lu et al., 2005 and Xia et al., 2008). The high yield of bioflocculant can meet the need for wide application.

Chemical analysis. Wu and Ye (2007) propose that the composition of bacterial bioflocculants plays a major role in their flocculating activities. Several types of bioflocculants have been reported including proteins, glycoproteins, polysaccharides, lipids and glycolipids (Salehizadeh and Shojaosadati, 2003). 


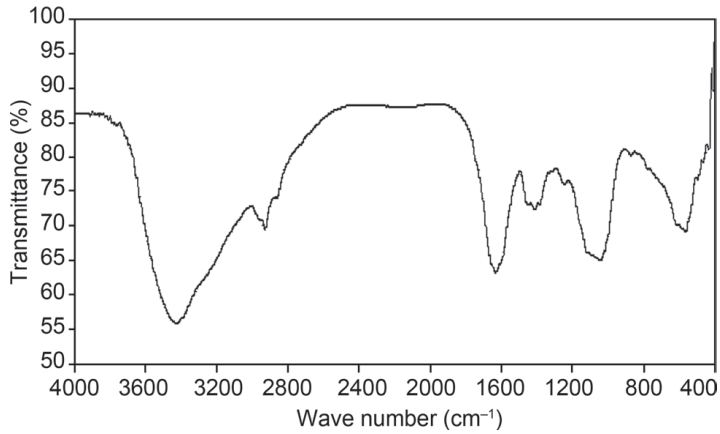

Fig. 2. Infrared spectra of purified bioflocculant from Pseudomonas aeruginosa ATCC-10145.

In this study, chemical analysis of the purified bioflocculant revealed that it was a sugar protein derivative composed of protein $(27 \%, \mathrm{w} / \mathrm{w})$ and carbohydrate $(89 \%, w / w)$ including neutral sugar, uronic acid and amino sugar as the principal constituents in the relative weight proportions of $30.6 \%, 2.35 \%$ and $0.78 \%$, respectively. Besides that, a ninhydrin-positive reaction illuminated that the bioflocculant contains amino acids. The elemental analysis of the bioflocculant revealed the mass proportion of $\mathrm{C}, \mathrm{H}$ and $\mathrm{N}$ was $19.06,3.88$ and 4.32 (\%), correspondently.

Sufficient content of uronic acid in a bioflocculant molecule can provide carboxyl groups to the molecular chain. The carboxyl groups presented on the molecular chain provided more effective sites for particles attachment, so many particles can be adsorbed to the long molecular chain (Aguilera et al., 2008).

Spectroscopic characterization. The functional groups in the polymer molecule are important determinants for the flocculating activity. FT-IR spectroscopy was performed on the purified bioflocculant between frequency ranges $4000-400 \mathrm{~cm}$ to analyze the functional groups (Fig. 2). The spectrum showed a broad stretching intense absorption peak at $3425.92 \mathrm{~cm}^{-1}$ characteristic for hydroxyl and amine groups. A weak $\mathrm{C}-\mathrm{H}$ stretching vibration band was observed at $2927.41 \mathrm{~cm}^{-1}$. Furthermore, an asymmetrical stretching peak was noticed at $1633.41 \mathrm{~cm}^{-1}$ and a week symmetrical stretching peak at $1445.39 \mathrm{~cm}^{-1}$, indicating the presence of carboxyl groups in the bioflocculant which may serve as binding sites for divalent cations. The carboxyl group may also work as functional moieties to generate new or modified polymer variants using different approaches like novel formulation, designing by linking such polymer with other synthetic polymers. The absorption peak at $1248.68 \mathrm{~cm}^{-1}$ was $\mathrm{S}=\mathrm{O}$ stretching indicated the presence of sulfate. Other bands observed in the range from 1000 to $1200 \mathrm{~cm}^{-1}$ are generally known to be typical characteristics of all sugar derivatives such as guluronic acid, manuronic acid and uronic acid (Suh et al., 1997). The small absorption band at about $870.703 \mathrm{~cm}^{-1}$ could be associated with $\beta$-glycosidic linkages between the sugar monomers, suggested by the study of Gupta et al. (1987). The $\mathrm{OH}, \mathrm{COOH}, \mathrm{COO}^{-}$groups in the bioflocculant and $\mathrm{H}^{+}, \mathrm{OH}^{-}$group on the surface of the particles may form hydrogen bonds when the bioflocculant chains approach the surface of particles (Deng et al., 2003). In conclusion, the infrared spectrum of this partially purified exopolymers thus showed the presence of carboxyl, hydroxyl (which are the preferred groups for flocculation process), amino and sugar derivative groups.

Heavy metal adsorption. In the present study, the bioflocculant produced by Pseudomonas aeruginosa exhibited different levels of heavy metal adsorption. Differences in affinity of metals for bioflocculants are due to charge density, attractive interaction and types of conformation of polymer with adsorbed ions (Morillo et al., 2006). The mechanism and kinet-

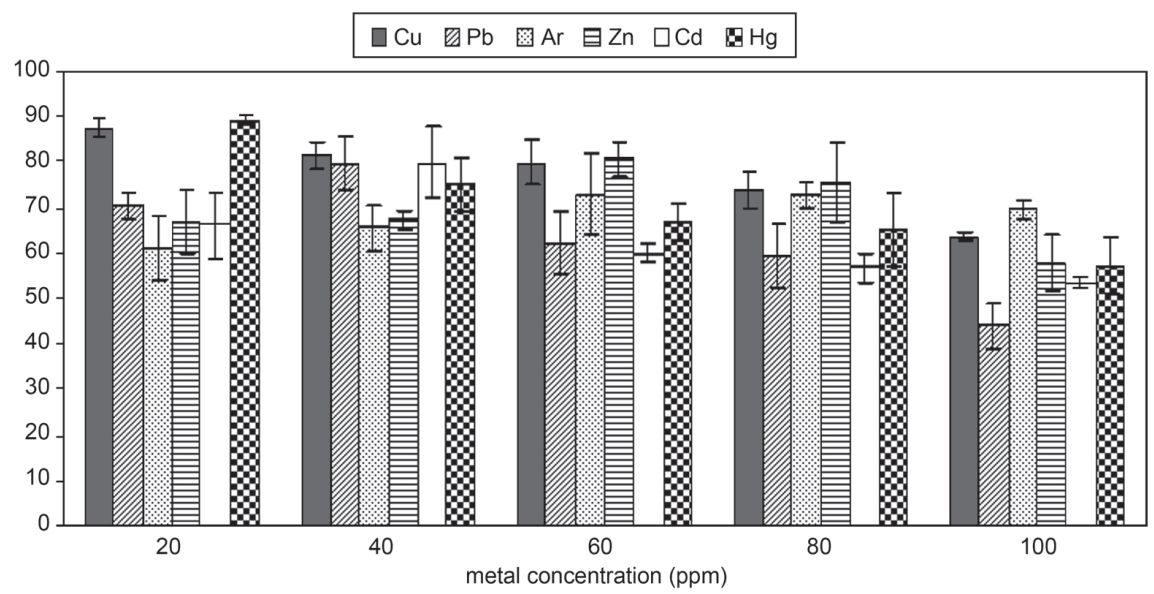

Fig. 3. Effect of metal concentration on the percentage of heavy metals removal using $100 \mathrm{ppm}$ bacterial bioflocculant. 


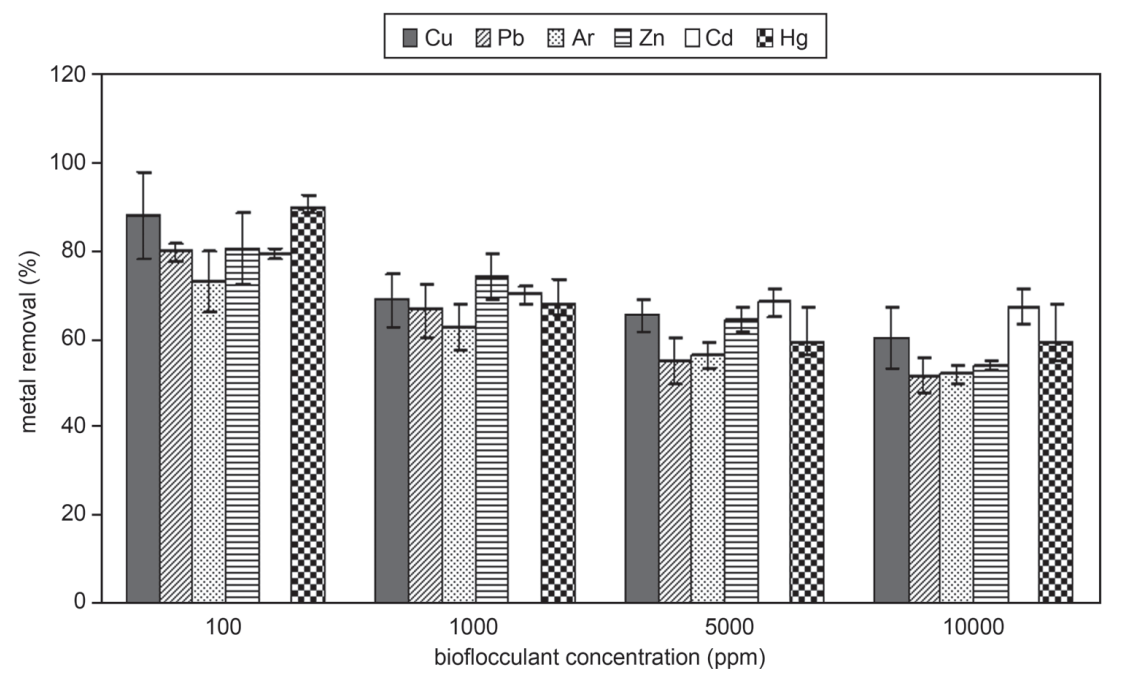

Fig. 4. Effect of bacterial bioflocculant concentration on the percentage of heavy metals removal. $\mathrm{Cu}^{2+}(20 \mathrm{ppm}), \mathrm{Pb}^{2+}(40 \mathrm{ppm}), \mathrm{As}^{2+}$ (60 ppm), $\mathrm{Zn}^{2+}$ (60 ppm), $\mathrm{Cd}^{2+}$ (40 ppm), $\mathrm{Hg}^{2+}$ (20 ppm).

ics of metal biosorption depends on the experimental conditions particularly, medium $\mathrm{pH}$, initial metal ion concentration and bioflocculant concentrations (Converti et al., 2006).

Results illustrated in Fig. 3 show that the heavy metals adsorption did not increase with the increase of initial concentrations. The bioflocculant showed the highest copper and mercury removal of $87.39 \%$ and $89.09 \%$, respectively at $20 \mathrm{ppm}$. The optimum ad sorption of lead $(79.70 \%)$ and cadmium (79.93\%) by the bioflocculant were recorded at $40 \mathrm{ppm}$, whereas, the highest arsenate and zinc removal of $72.96 \%$ and $80.59 \%$, respectively was recorded at $60 \mathrm{ppm}$. The enhancement in metal adsorption could be due to an increase in electrostatic interactions, involving sites of progressively lower affinity for metal ions (Puranik and Pakniker,
1999). Therefore, there was no increase in metal uptake where the binding sites were saturated by the metals.

It is clear from the results presented in Fig. 4 that the bioflocculant exhibited a better efficiency for removal of heavy metals at lower bioflocculant concentration as described by others (Das and Santra, 2007). Higher efficiencies in removing heavy metals at the low bioflocculant concentrations make them very attractive in the treatment of industrial effluents/wastewaters.

The effect of $\mathrm{pH}$ on the adsorption of heavy metals was examined at $\mathrm{pH} 3.0,5.0,7.0$ and 9.0. The results presented in Fig. 5 show that the highest adsorption of $\mathrm{Cu}^{2+}, \mathrm{pb}^{2+}, \mathrm{Cd}^{2+}$ and $\mathrm{Hg}^{2+}$ were reported at $\mathrm{pH} 7$ whereas, the highest adsorption of $\mathrm{As}^{2+}$ and $\mathrm{Zn}^{2+}$ were reported at $\mathrm{pH} 9$. Heavy metals adsorption was low at low and high $\mathrm{pH}$ values; it was reported that at low $\mathrm{pH}$

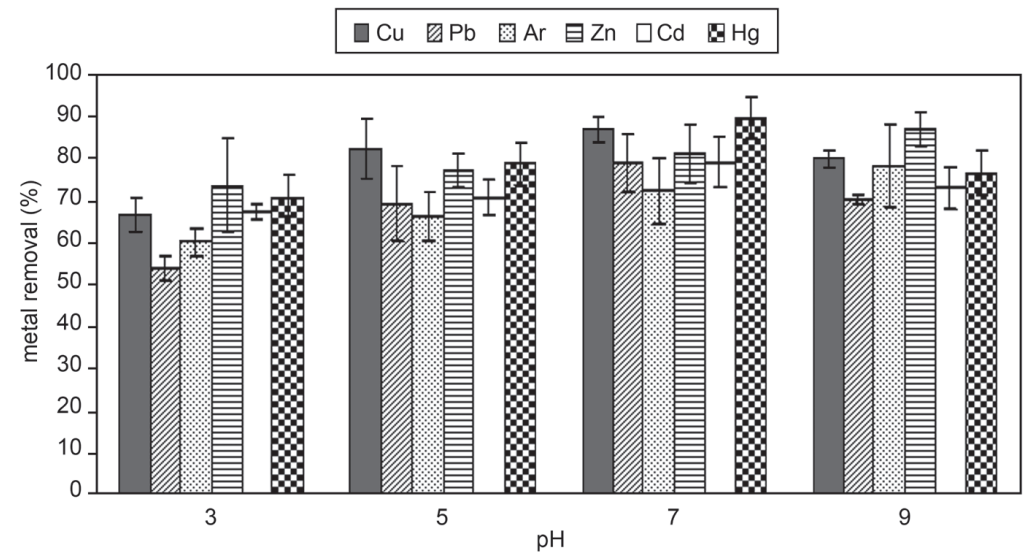

Fig. 5. Effect of $\mathrm{pH}$ on the percentage of heavy metals removal using $100 \mathrm{ppm}$ bacterial bioflocculant. 
values, a high concentration of protons competes for the same anionic sites on the polymer as the divalent cations. The mass of protons leads to their preferential binding and thus divalent cation binding is low (Sahoo et al.,1992). As the $\mathrm{pH}$ increases to its optimum value, which differ from one metal ion to another, the adsorbing surface saturated with negative charges, resulted in increased efficiency to bind and adsorb metal ions of positive charges (Bayramoglu et al., 2003). While at $\mathrm{pH}$ higher than its optimum value, hydroxo species of the metals can be formed and do not bind to the adsorption sites on the surface of the adsorbent (Kacar et al., 2000). Therefore, this study details important implications in providing a safer alternative flocculation method for wastewater treatment.

\section{Literature}

Aguilera M., M.T. Quesada, V.G.Aguila, J.A. Morillo, M.A. Rivadeneyra, A.R. Cormenzana and M.M. Sanchez. 2008. Characterization of Paenibacillus jamilae strains that produce exopolysaccharide during growth on and detoxification of olive mill wastewaters. Bioresour. Technol. 99: 5640-5644.

Al-Garni S.M., K.M. Ghanem and A.S. Bahobail. 2009. Biosorption characteristics of Aspergillus fumigatus in removal of cadmium from an aqueous solution. Afr. J. Biotechnol. 8: 4163-4172.

Arezoo C. 2002. The potential role of aluminium in Alzheimer's disease. Nephrol. Dial. Transplant. 17: 17-20.

Bayramoglu G., S. Baktas and M.Y. Arica. 2003. Biosorption of heavy metal ions on immobilized white-rot fungus Trametes versicolor. J. Hazard. Mater. 101: 285-300.

Boening D.W. 2000. Ecological effects, transport, and fate of mercury: a general review. Chemosphere. 40: 1335-1351.

Chaplin M.F. and J.F. Kennedy. 1994. Carbohydrate Analysis, second ed. Oxford University Press, NewYork.

Choi C.W., S.A. Yoo, I.H. Oh and S.H. Park. 1998. Characterization of an extracellular flocculating substance produced by a planktonic cyanobacterium, Anabaena sp. Biotechnol. Lett. 20: 643-646. Converti A., A. Lodi, C. Solisio, D. Soletto, M. Del Borghi and J.C. Carvalho. 2006. Spirulina platensis biomass as adsorbent for copper removal. Cienc. Technol. Aliment. 5: 85-88.

Das S. and S.C. Santra. 2007. Microbial interactions with heavy metals and their applications in bioremediation of wastewater. New Frontiers of Environ. Biotechnol. Appl. 3: 1-10.

Deng S. B., R.B. Bai, X.M. Hu and Q. Luo. 2003. Characteristics of a bioflocculant produced by Bacillus mucilaginosus and its use in starch waste-water treatment. Appl. Microbiol. Biotechnol. 60: 588-593.

Diels L., N. Van der Lelie and L. Bastiaens. 2002. New development in treatment of heavy metal contaminated soils. Rev. Environ. Sci. Biotechnol. 1: 75-82.

Fujita M., M. Ike, S. Tachibana, G. Kitada, S.M. Kim and Z. Inoue. 2000. Characterization of a bioflocculant produced by Citrobacter sp. TKF04 from acetic and propionic acids. J. Biosci. Bioeng. 89: 40-46. Gao J., H.Y. Bao, M.X. Xin, Y.X. Liu, Q. Li and Y.F. Zhang. 2006. Characterization of a bioflocculant from a newly isolated Vagococcus sp. W31. J. Zhejiang Univ. Sci. B. 7: 186-192.

Gourdon R., S. Bhende, E. Rus and S.S. Sofer. 1990. Comparison of cadmium biosorption by Gram-positive and Gram-negative bacteria from activated sludge. Biotechnol. Lett. 12: 839-842.
Gupta S., R.N. Madan and M.C. Bansal. 1987. Chemical composition of Pinus caribaea hemicellulose. TAPPI J. 70: 113-114.

He J., J. Zou, Z. Shao, J. Zhang, Z. Liu and Z.Yu. 2010. Characteristics and flocculating mechanism of a novel bioflocculant HBF-3 produced by deep-sea bacterium mutant Halomonas sp. World J. Microbiol. Biotechnol. 26: 1135-1141.

He N., Y. Li and J. Chen. 2004. Production of a novel polygalacturonic acid biofloccualnt REA-11 by Corynebacterium glutamicum. Bioresour. Technol. 94: 99-105.

Kacar Y., C. Arpa, S. Tan, A. Denizli, O. Genc and M.Y. Arica. 2000. Biosorption of $\mathrm{Hg}$ (II) and $\mathrm{Cd}$ (II) from aqueous solution: Comparison of biosorptive capacity of alginate and immobilized live and heat inactivated Phanerochaete chrysosporium. Process Biochem. 37: 601-610.

Kumar C.G., H.S. Joo, J.W. Choi, Y. Koo and C. Chang. 2004. Purification and characterization of an extracellular polysaccharide from haloalkalophillic Bacillus sp. I-450. Enzyme Microb. Technol. 34: 673-681.

Kurane R., S. Hatakeyama and H. Tsugeno. 1991. Correlation between flocculation production and morphological changes in Rhodococcus erythropolis S-1. J. Ferment. Bioeng. 72: 498-500.

Li W.W., W.Z. Zhou, W.Z. Zhang, J. Wang and X.B. Zhu. 2008. Flocculation behaviour and mechanism of an exopolysaccharide from the deep-sea psychrophilic bacterium Pseudoalteromonas sp. SM9913. Bioresour. Technol. 99: 6893-6899.

Lin J. and C. Harichund. 2011. Isolation and characterization of heavy metal removing bacterial bioflocculants. African J. Microbiol. Res. 5: 599-607.

Lowry O.H., N.J. Rosebrough, A.L. Farr and R.J. Randall. 1951. Protein measurement with the Folin phenol reagent. J. Biol. Chem. 193: 265-275.

Lu W.Y., T. Zhang, D.Y. Zhang, C.H. Li, J.P. Wen, L.X. Du. 2005. A bioflocculant produced by Enterobacter aerogenes and its use in defecating the trona suspension. Biochem. Eng. J. 27: 1-7.

Morillo J.A., M. Aguilera, A.R. Cormenzana and M.M. Sanchez. 2006. Production of a metal-binding exopolysaccharide by Paenibacillus jamilae using two phase olive mill waste as fermentation substrate. Curr. Microbiol. 53: 189-193.

Nakata K. and R. Kurane. 1999. Production of an extracellular polysaccharide bioflocculant by Klebsiella pneumonia. Biosci. Biotechnol. Biochem. 63: 2064-2068.

Nasser M.S. and A.E. James. 2007. Effect of polyacrylamide polymers on flocculant size and rheological behaviour of kaolinite suspensions. Colloids Surf. A. 301: 311-322.

Puranik P.R. and K.M. Pakniker. 1999. Biosorption of lead, cadmium and zinc by Citrobacter strain MCM B-181: Characterization studies. Biotechnol. Prog. 15: 228-237.

Ruden C. 2004. Acrylamide and cancer risk-expert risk assessments and the public debate. Food Chem. Toxicol. 42: 335-349.

Sahoo D.K., R.N. Kar and R.P. Das. 1992. Bioaccumulation of heavy metal ions by Bacillus circulans. Bioresour. Technol. 41: 177-179.

Salehizadeh H. and S.A. Shojaosadati. 2001. Extracellular biopolymeric flocculants-recent trends and biotechnological importance. Biotechnol. Adv. 19: 371-385.

Salehizadeh H. and S.A. Shojaosadati. 2003. Removal of metal ions from aqueous solution by polysaccharide produced from Bacillus firmus. Water Res. 37: 4231-4235.

Sheng Y., Q. Zhang, Y. Sheng, C. Li and H. Wang. 2006. Screening and flocculating properties of bioflocculant-producing microorganisms. Sci. Technol. 13: 289-292.

Suh H.H., G.S. Kwon, C.H. Lee, H.S.Kim, H.M. Oh, B.D.Yoon. 1997. Characterization of bioflocculant produced by Bacillus sp. DP-152. J. Ferment. Bioeng. 84: 108-112. 
Takagi H. and K. Kadowaki. 1985. Polygalactosamine produced by a microorganism.Chitin. Nat. Technol. 3: 121-128.

Tong Z., L. Zhe and Z. Huailan. 1999. Microbial flocculant and its application in environmental protection. J. Environ. Sci. 11: 1-12.

Wu J.Y. and H.F. Ye. 2007. Characterization and flocculating properties of an extracellular biopolymer produced from a Bacillus subtilis DYU1 isolate. Process Biochem. 42: 1114-1123.

Xia S., Z. Zhang, X. Wang, A. Yang, L. Chen, J. Zhao, D. Leonard and N. Jaffrezic-Renault. 2008. Production and characterization of a bioflocculant by Proteus mirabilis TJ-1. Bioresource Technol. 99: 6520-6527

Xiong Y., Y. Wang, Y. Yu, Q. Li, H. Wang, R. Chen and N. He. 2010. Production and characterization of a novel bioflocculant from Bacillus licheniformis. Appl. Environ. Microbiol. 76: 2778-2782.
Yan G.Y. and T. Viraraghavan. 2001. Heavy metal removal in a biosorption column by immobilized Mucor rouxii biomass. Bioresour. Technol. 78: 243-249.

Zhang W. 2003. Biological-chemical analysis of Glycoconjugates, second ed. Zhejiang University Press, Zhejiang.

Zhang Z.Q. 2005. Study on microbial flocculants produced by multiple microorganisms. Nanchang Univeristy Press, Nanchang.

Zhang Z.Q., B. Lin, S.Q. Xia, X.J. Wang, A.M. Yang. 2007. Production and application of a novel bioflocculant by multiple microorganism consortia using brewery wastewater as carbon source. J. Environ. Sci. 19: 667-673.

Zheng Y., Z.L. Ye, X.L. Fang, Y.H. Li, W.M. Cai. 2008. Production and characteristics of a bioflocculant produced Bacillus sp. F19. Bioresour. Technol. 99: 7686-7691. 